\title{
From Italian Pushbacks to Libyan Pullbacks: Is Hirsi 2.0 in the Making in Strasbourg?
}

\author{
Annick Pijnenburg \\ Tilburg Law School, Tilburg University, the Netherlands \\ a.pijnenburg@uvt.nl
}

\begin{abstract}
This article discusses the application that was recently lodged with the European Court of Human Rights alleging that Italy is responsible for its involvement in pullbacks by the Libyan coast guard. It places the case in the wider context of migration control policies and the Hirsi case in particular. The article examines different pullback scenarios which feature in the application lodged with the Court, and discusses different ways in which the Court can address the issues raised. The analysis focuses particularly on the question whether the Court is likely to find that Italy exercises jurisdiction and whether Italy could incur derived responsibility for its involvement in the pullbacks. The article concludes by suggesting that holding Italy responsible would require the Court to move beyond established precedent in its case-law. Although this is a move which can be difficult to make given the political tide in Europe, it would not be the first time that the Court takes its case-law, and thereby human rights protection, a step further.
\end{abstract}

\section{Keywords}

European Court of Human Rights - pullbacks - migration control - Hirsi - Italy Libya - responsibility 
In 2008 Italy and Libya signed a Treaty on Friendship, Partnership and Cooperation aimed at preventing irregular migration from Libya to Italy. Under that agreement, Italy carried out several naval operations whereby it intercepted irregular migrants and returned them to Libya. ${ }^{1}$ These were condemned by the European Court of Human Rights (ECtHR or Court) in the case of Hirsi Jamaa and Others $v$ Italy. ${ }^{2}$ The Friendship Treaty was suspended in 2011 due to the civil unrest in Libya. However, in February 2017 Italy and Libya concluded a new memorandum of understanding. Under this new agreement, Italy provides support to the Libyan Coast Guard (LCG), which intercepts migrant boats which try to cross from Libya to Italy, and returns the passengers to Libya. ${ }^{3}$ In this context, an application was filed with the ECtHR, arguing that Italy is responsible for a fatal rescue incident involving an Italian and Libyan vessel, as a result of which at least twenty migrants died and survivors suffered severe human rights violations in Libya. ${ }^{4}$ This raises the following questions: how will the Court decide in this case? Will it find, as it did in Hirsi, that Italy breached its obligations under the Convention? Or will it find that these facts do not trigger Italy's responsibility?

The aim of this article is to explore the different ways in which the Court may choose to address this new case, rather than making a particular suggestion on

* The author would like to thank the participants of the seminar on 'Controlling Migration through Cooperation' held at Tilburg University on 2 February 2018 for the feedback received. Special thanks go to Thomas Gammeltoft-Hansen, Conny Rijken, Maarten den Heijer and Thomas Spijkerboer. Any remaining mistakes are my own.

1 In this article, the word 'migrant' refers to irregular migrants who attempt to cross the Mediterranean Sea from Italy to Libya. This includes asylum seekers who may be entitled to refugee status or subsidiary protection.

2 Hirsi Jamaa and Others v Italy [GC] App no 27765/o9 (ECtHR, 23 February 2012).

3 On Italian-Libyan cooperation to control migration flows see: F. Mussi \& N.F. Tan, Comparing Cooperation on Migration Control: Italy-Libya and Australia-Indonesia, in: F. de Londras \& S. Mullally (Eds), Irish Yearbook of International Law 2015, Vol. 10 (Oxford: Hart Publishing, 2017); C. Heller \& L. Pezzani, Mare Clausum: Italy and the EU's Undeclared Operation to Stem Migration across the Mediterranean, Forensic Oceanography, May 2018, https://www.forensic -architecture.org/case/sea-watch/ (accessed 23 May 2018); M. Giuffré, State Responsibility Beyond Borders: What Legal Basis for Italy's Push-backs to Libya?, 24(4) International Journal of Refugee Law 2012, p. 692-734.

4 Global Legal Action Network, Legal Action Against Italy over its Coordination of Libyan Coast Guard Pull-backs Resulting in Migrant Deaths and Abuse (London: GLAN, 8 May 2018), http:// www.glanlaw.org/single-post/2018/05/08/Legal-action-against-Italy-over-its-coordinationof-Libyan-Coast-Guard-pull-backs-resulting-in-migrant-deaths-and-abuse (accessed 22 May 2018). 
how it should decide. The latter would arguably be premature, as the case is only in its early stages and hence any analysis remains speculative. Moreover, in terms of scholarly examination the chosen approach offers more opportunity for discussing various strands of case-law on which the Court could draw and reflecting on academic debates surrounding key issues.

As the facts of the new application include different aspects which are relevant for the question of Italy's responsibility, discussing them separately helps clarify the analysis. Moreover, various other interceptions by the LCG have also been reported, suggesting specific patterns of Italian involvement. ${ }^{5}$ The analysis will therefore explore various scenarios in turn, since, in addition to being relevant for the case pending before the ECtHR, these or similar incidents could give rise to another application being brought to the ECtHR.

The analysis is limited to the responsibility of Italy, as it is the only respondent State in both the Hirsi and the new case, and does not discuss the possible responsibility of other actors. Likewise, this article focuses principally on the ECtHR's own case-law rather than that of other bodies, as this is what the Court itself does, while acknowledging that a complete analysis of issues such as jurisdiction and State responsibility would need to look beyond the ECtHR's case-law. Due to the limited scope of this article the analysis focuses on Article $3 \mathrm{ECHR}$ (prohibition of torture and inhuman or degrading treatment), although it is acknowledged that other rights may also be at stake, such as the prohibition of collective expulsions, the right to life, the prohibition of slavery and forced labour, the right to liberty and security, the right to leave and the right to an effective remedy. ${ }^{6}$ Last, adopting the perspective of the Court for the analysis does not reflect an endorsement of the Court's approach or suggest that an application to the ECtHR is the only possible avenue for establishing the responsibility of the actors involved.

The article is structured as follows. Section 2 discusses the Hirsi case and its significance for migration control policies. Section 3 discusses current migration control arrangements between Italy and Libya and the facts on which the recent application to the Court is based. It also places the case within the broader context in which the Court has to rule. Sections 4 to 6 present different pullback scenarios, based on elements from the application and other reported incidents. Last, Section 7 offers some concluding thoughts.

5 See for instance Heller \& Pezzani (n. 3), p. 57-82.

6 In the Hirsi case for instance the ECtHR found a violation of Articles 3 (prohibition of torture) and 13 (right to an effective remedy) ECHR as well as Article 4 of Protocol 4 to the ECHR (prohibition of collective expulsion of aliens). 
The sharp increase in the number of migrants trying to reach the EU in 20152016, commonly referred to as the refugee crisis, has led to a number of policy developments aimed at controlling migration flows, such as Italy's memorandum of understanding with Libya and the EU-Turkey Statement. ${ }^{7}$ However, migration control policies are not a new phenomenon. Rather, destination States in Europe but also the USA and Australia have implemented policies to control irregular migration flows since the 1980 s. Yet the nature of these policies has changed over time: some of the first measures introduced included visa requirements and carrier sanctions as well as pushbacks on the high seas, whereas more recent developments include the financing, equipping and training of States of origin and transit to stem migration flows. ${ }^{8}$

In the specific context of the Central Mediterranean, cooperation between Italy and Libya started in 2000 with an agreement for collaboration in the fight against terrorism, organised crime, illegal traffic of drugs, and irregular immigration. It was followed by various other agreements concluded between 2003 and 2009, including a 2007 Additional Operating and Technical Protocol on cooperation in the fight against irregular immigration, the 2008 Treaty on Friendship, Partnership, and Cooperation, and a 2009 Executive Protocol of the 2007 agreements. ${ }^{9}$ The arrangements between Italy and Libya included the provision of funding, equipment and other assistance as well as training by Italy to Libya, the return of migrants to Libya and their repatriation from Libya to third countries, joint patrols in the Mediterranean, and exchange of intelligence. In practice, between May and November 2009 Italian vessels intercepted and returned over 800 persons to Libya. ${ }^{10}$

The Hirsi case concerned one such interception: 11 Somali nationals and 13 Eritrean nationals, who were part of a group of some 200 individuals who

European Council, EU-Turkey Statement, 18 March 2016. Press Release 144/16, http:// www.consilium.europa.eu/en/press/press-releases/2016/o3/18-eu-turkey-statement/ (accessed 7 August 2017).

8 On migration control policies more generally see T. Gammeltoft-Hansen \& J.C. Hathaway, Non-Refoulement in a World of Cooperative Deterrence, 53(2) Columbia Journal of Transnational Law 2015, p. 235-283; B. Frelick, I.M. Kysel \& J. Podkul, The Impact of Externalization of Migration Controls on the Rights of Asylum Seekers and Other Migrants, 4(4) Journal on Migration and Human Security 2016, p. 190-220; M. den Heijer, Europe and Extraterritorial Asylum (Oxford: Hart Publishing, 2012); T. GammeltoftHansen, Access to Asylum: International Refugee Law and the Globalisation of Migration Control (Cambridge: Cambridge University Press, 2011).

$9 \quad$ Giuffré (n. 3), p. 700-703.

$10 \quad$ Mussi \& Tan (n. 3), p. 91-92. 
left Libya on three vessels with the aim of reaching Italy, were intercepted by three ships from the Italian Revenue Police and Coastguard on the high seas. They were transferred onto Italian military ships and returned to Tripoli, where they were handed over to the Libyan authorities. ${ }^{11}$

The Grand Chamber made a number of pronouncements in this case which are relevant for European migration control policies more broadly. ${ }^{12}$ First, the Court confirmed that a State exercises jurisdiction when intercepting vessels on the high seas. This could be read as an affirmation of its general principles on jurisdiction as laid down in Al-Skeini and earlier cases, according to which a State exercises extraterritorial jurisdiction when it exercises authority and control over a person outside its territory. ${ }^{13}$ More specifically, the Court clarified in Hirsi that, as the applicants were on board Italian ships with crews composed of Italian military personnel, they were 'under the continuous and exclusive de jure and de facto control of the Italian authorities. ${ }^{.14}$

Second, Hirsi also confirmed that the assessment of a State's human rights obligations is not affected by its obligations under other legal regimes, nor by its agreements with other States. ${ }^{15}$ Thus, a State cannot evade its responsibilities under the Convention by referring to other international obligations. As regards regime interaction, the Court noted that 'Italy cannot circumvent its "jurisdiction" under the Convention by describing the events in issue as rescue operations on the high seas. ${ }^{16}$ In other words, the international obligations arising from other international regimes such as the law of the sea, especially as regards search and rescue (SAR) operations, do not displace obligations under the Convention. Likewise, the Court dismissed Italy's argument that the applicants had been transferred to Libya in accordance with the bilateral

\footnotetext{
11 Hirsi, paras. 9-12.

12 For a more detailed analysis of the Hirsi case see: M. Giuffré, Watered-down Rights on the High Seas: Hirsi Jamaa and Others v. Italy, 61(3) International and Comparative Law Quarterly 2012, p. 728-750; M. den Heijer, Reflections on Refoulement and Collective Expulsion in the Hirsi Case, 25(2) International Journal of Refugee Law 2013, p. 265290; V. Moreno-Lax, Hirsi Jamaa and Others $v$ Italy or the Strasbourg Court versus Extraterritorial Migration Control?, 12(3) Human Rights Law Review 2012, p. 574-598.

13 See Al-Skeini and Others $v$ the United Kingdom [GC] App no 55721/o7 (ECtHR, 7 July 2011), paras. 131-39; Bankovic and Others $v$ Belgium and Others [GC] App No 52207/99 (ECtHR, 12 December 2001), paras. 59-73.

14 Hirsi, para. 81.

15 See also T. Gammeltoft-Hansen, Extraterritorial Migration Control and the Reach of Human Rights, in: V. Chetail \& C. Bauloz (Eds), Research Handbook on International Law and Migration (Cheltenham: Edward Elgar Publishing, 2014), p.113-131; Den Heijer (n. 12), p. 271-272.

16 Hirsi, para. 79 .
} 
agreements signed by Italy and Libya. It stated explicitly that 'Italy cannot evade its own responsibility by relying on its obligations arising out of bilateral agreements with Libya' and recalled that its responsibility 'continues even after their having entered into treaty commitments subsequent to the entry into force of the Convention or its Protocols.' ${ }^{17}$

Third, in Hirsi the Court held that the prohibition of collective expulsions in Article 4 of Protocol No. 4 to the ECHR applied to interceptions on the high seas 'the effect of which is to prevent migrants from reaching the borders of the State or even to push them back to another State'.18 The fact that the specific circumstances of each individual were not the subject of a detailed examination meant that this provision had been breached. In this regard, Hirsi distinguishes itself from the US Supreme Court's Sale ruling, which held that the prohibition of refoulement did not apply to interceptions on the high seas. ${ }^{19}$ Hirsi, on the other hand, affirms that the prohibition of refoulement also applies extraterritorially. ${ }^{20}$ In short, the Court in Hirsi clarified that States parties to the ECHR are prohibited from intercepting irregular migrants on the high seas and returning them to another State without giving them access to an asylum procedure and investigating whether they can be safely returned.

Last, on the merits the ECtHR found that there had been a violation of Article 3 ECHR on account of the fact that the applicants were exposed to the risk of being subjected to ill-treatment in Libya as well as the fact that they were exposed to the risk of being repatriated to Somalia and Eritrea (also known as chain refoulement). Thus, the prohibition of returns to unsafe countries applies to all irregular migrants and not only to refugees: 'the Italian authorities knew or should have known that, as irregular migrants, they would be exposed in Libya to treatment in breach of the Convention.' ${ }^{21}$ Moreover, the judgment suggests that States must proactively investigate whether intercepted individuals can be safely returned. ${ }^{22}$

However, there are also several issues which Hirsi left unaddressed. In particular, one question which the judgment left unanswered concerns Italy's

17 Hirsi, para. 129. See also Al-Saadoon and Mufdhiv the United Kingdom App No 61498/08 (ECtHR, 2 March 2010), para. 128.

18 Hirsi, para 180.

19 Chris Sale, Acting Commissioner, Immigration and Naturalization Service et al. $v$ Haitian Centers Council Inc et al, 509 US 155, United States Supreme Court 21 June 1993, p. 184.

20 The ECtHR can be seen to follow the Inter-American Commission on Human Rights' interpretation. See Haitian Centre for Human Rights and Others $v$ USA Case 10.675 (IAComHR, 13 March 1997), para 157.

21 Hirsi, para. 131. See also Den Heijer (n. 12), p. 277-78.

22 Hirsi para 133. See also Moreno-Lax (n. 12), p. 583. 
exercise of jurisdiction: although the judgment clarifies that the transfer of irregular migrants onto military ships on the high seas triggers Italy's jurisdiction, it does not say whether this is also the case with other forms of interception: what if the Italian vessels had forced the migrant boats to return to Tripoli without transferring the migrants to their own vessels? What if an Italian-Libyan joint patrol had carried out the interception? Furthermore, the Court did not address the other aspects of Italy's cooperation with Libya under the Friendship Treaty and Protocols, such as the provision of funding, training, and equipment by Italy. This may be due to the fact that the Court was asked to rule on the responsibility of Italy in regard to a specific incident, rather than pass judgment on Italy's cooperation with Libya more generally. ${ }^{23}$ Yet, as the rest of this article will show, these questions play a crucial role in today's pullback practices.

This section discusses the current situation in the Central Mediterranean. It describes the migration control policies implemented by Italy after Hirsi as well as the specific facts of the new application, and reflects on the context in which the ECtHR has to rule in this case.

\subsection{Migration Control in the Central Mediterranean after Hirsi}

In February 2017 Italy and Libya signed a new Memorandum of Understanding on Cooperation on Development, Combatting Illegal Immigration, Human Trafficking and Smuggling, and on Strengthening Border Security. ${ }^{24}$ They thereby agreed to implement cooperation initiatives as foreseen in previous bilateral agreements, especially Article 19 of the 2008 Treaty on Friendship, Partnership and Cooperation, which makes provision for efforts to prevent clandestine immigration in the countries of origin of migratory flows. ${ }^{25}$ Italy further agreed to provide support and financing for development programmes in the regions affected by illegal immigration as well as technical and

\footnotetext{
23 See also Thomas Gammeltoft-Hansen's contribution in this special issue.

24 Memorandum of Understanding on Cooperation on Development, Combatting Illegal Immigration, Human Trafficking and Smuggling, and on Strengthening Border Security (Torino: ASGI, 2 February 2017), unofficial translation available at http://www.asgi .it/wp-content/uploads/2017/02/ITALY-LIBYA-MEMORANDUM-02.02.2017.pdf (accessed 10 August 2017). For a detailed overview of Italian cooperation with Libya, see Heller \& Pezzani (n. 3).

25 See Hirsi, para. 20.
} 
technological support to the Libyan institutions in charge of the fight against illegal immigration, including the border and coast guard. Last, Italy finances the initiatives agreed on, while Italy and the EU also finance migrant hosting centres and Italy contributes medical supplies to these centres. ${ }^{26}$

Moreover, in summer 2017 the Italian parliament authorised a naval mission (operation Mare Sicuro) to provide technical support to the LCG. ${ }^{27}$ In December 2017 Italy and Libya also agreed to establish a joint operations room for fighting migrant smuggling and trafficking. ${ }^{28}$ At the same time, Italy has imposed a code of conduct on NGOs carrying out rescues in the Central Mediterranean and seized two NGO ships on allegations of facilitation of irregular migration..$^{29}$ More recently, in summer 2018, Libya declared its SAR zone and Italy handed over SAR responsibility to Libya; ${ }^{30}$ Italy and Libya reactivated the 2008 Friendship Treaty; ${ }^{31}$ and Italy provided the LCG with more vessels and other equipment. ${ }^{32}$ Italy also closed its ports to rescued migrants in June $2018^{33}$ and allegedly pressured Panama into deflagging the last NGO vessel still active in the Central Mediterranean in September 2018. ${ }^{34}$

26 Memorandum of Understanding (n. 24). See also A. Palm, Das Memorandum of Understanding zwischen Italien und Libyen als Basis für einen Politikansatz, der alle Türen nach Europa schliessen will?, 4/17 Asyl 2017, p. 3-7.

27 Agence France Presse, Italy Impounds NGO Rescue Ship and Sends Navy Patrol Boat to Libya. The Guardian 21 August 2017, https://www.theguardian.com/world/2017/aug/o2/ italy-impounds-ngo-rescue-ship-sends-navy-patrol-boat-to-libya-migrant-refugee-route -europe (accessed 21 August 2017).

28 Reuters Staff, Libya and Italy to set up Operations Room to Tackle Migrant Smuggling (Tripoli: Reuters, 9 December 2017), https://www.reuters.com/article/us-europe-migrants -libya/libya-and-italy-to-set-up-operations-room-to-tackle-migrant-smuggling-idUSKBN 1E3oL8?mc_cid=6c6c76odce\&mc_eid=28c3b9e46a (accessed 26 January 2018).

29 D. Howden, Europe's New Anti-migrant Strategy? Blame the Rescuers, Prospect Magazine, 20 March 2018, https://www.prospectmagazine.co.uk/magazine/europes-new-anti-migrant -strategy-blame-the-rescuers? (accessed 19 April 2018).

30 B. Riegert, Libya takes over from Italy on Rescuing Shipwrecked Migrants, Deutsche Welle 5 July 2018, https://p.dw.com/p/3oue2 (accessed 19 September 2018).

31 D. Bellamy, Italy promises Billions of Euros to Libya if it accepts the Return of Migrants, Euronews 8 July 2018, https://www.euronews.com/2018/07/08/italy-promises-billions-ofeuros-to-libya-if-it-accepts-the-return-of-migrants (accessed 19 September 2018).

32 Deutsche Welle, Italy gives Libya Ships, Equipment as more Migrants reported lost, Deutsche Welle 3 July 2018, https://p.dw.com/p/30ig6 (accessed 19 September 2018).

33 B BC, Migrant Crisis: Italy Minister Salvini closes Ports to NG O Boats (London: BBC, 30 June 2018), https://www.bbc.com/news/world-europe-44668062 (accessed 19 September 2018).

34 M. Weaver, Charities Plea for Help after Aquarius Migrant Rescue Ship's Flag Revoked, The Guardian 24 September 2018, https://www.theguardian.com/world/2018/sep/24/italy -blamed-after-aquarius-migrant-rescue-ships-flag-revoked (accessed 24 September 2018). 
Furthermore, the EU is also involved in Libya through, amongst others, the Malta Declaration, ${ }^{35}$ Eunavfor MEd Operation Sophia, ${ }^{36}$ the EU's Border Assistance Mission to Libya ${ }^{37}$ (EUBAM) and the EU Emergency Trust Fund for Africa. ${ }^{38}$ Numerous reports suggest that the human rights situation of migrants, including refugees, in Libya is extremely dire, including killings, torture, arbitrary detention, rape, forced labour and slavery. ${ }^{39}$ UNHCR thus 'urges all States to suspend forcible returns to Libya until the security and human rights situation has improved considerably. ${ }^{40}$

\subsection{The GLAN-ASGI Case}

It is in this context that in May 2018 the Global Legal Action Network (GLAN) and the Association for Juridical Studies on Immigration (ASGI), with support from the Italian non-profit ARCI and Yale Law School's Lowenstein International Human Rights Clinic, filed an application with the ECtHR on behalf of 17 survivors of a fatal incident in which a migrant boat found itself in distress off the coast of Libya on 6 November 2017. According to the

35 European Council, Malta Declaration by the Members of the European Council on the External Aspects of Migration: Addressing the Central Mediterranean Route, Press Release 43/17 (Brussels: European Council, 3 February 2017), http://www.consilium.europa.eu/en/ press/press-releases/2017/01/o3-malta-declaration/ (accessed 10 August 2017), para. 6(i).

36 Council of the European Union, Council Decision (CFSP) 2016/993 of 20 June 2016 Amending Decision (CFSP) 2015/778 on a European Union Military Operation in the Southern Central Mediterranean (EUNAVFor MED Operation sophia), Article 1.

37 Council of the European Union, EUBAM Libya: Mission Extended, Budget Approved, Press Release 482/16, (Luxembourg: Council of the European Union, 4 August 2016), http:// www.consilium.europa.eu/en/press/press-releases/2016/08/04-eubam-libya-mission -extended/ (accessed 20 September 2017).

38 European Commission, EU Emergency Trust Fund for Africa: Libya (Brussels: European Commission), https://ec.europa.eu/trustfundforafrica/region/north-africa/libya_en (accessed 3 May 2018).

39 See for instance Amnesty International, Libya's Dark Web of Collusion: Abuses against Europe-Bound Refugees and Migrants (London: Amnesty International, 2017), https:// www.amnesty.org/download/Documents/MDE1975612017ENGLISH.PDF (accessed 3 May 2018); Refugees International, 'Hell on Earth': Abuses Against Refugees and Migrants Trying to Reach Europe from Libya (Washington: Refugees International, 2017), https:// static1.squarespace.com/static/506c8ea1e4bo1d945odd53f5/t/592f37468419c2ac554b 4c9f/1496266580341/2017.6.1+Libya.pdf (accessed 10 August 2017); Office of the High Commissioner for Human Rights, UN Human Rights Chief: Suffering of Migrants in Libya Outrage to Conscience of Humanity (Geneva: UNHCR, 14 November 2017), http://www .ohchr.org/EN/NewsEvents/Pages/DisplayNews.aspx?NewsID=22393\&LangID=E (accessed 29 November 2017).

40 UN High Commissioner for Refugees (UNHCR), UNHCR Position on Returns to LibyaUpdate II (Geneva: UNHCR, September 2018), http://www.refworld.org/docid/5b8do2314 .html (accessed 17 September 2018). 
application, at least 20 migrants died when the LCG interfered with the efforts of the NGO vessel Sea Watch to rescue 130 migrants from a sinking dinghy. ${ }^{41}$

The application is based on a reconstruction of the incident of 6 November 2017. According to this reconstruction, the passengers of a migrant boat made a distress call to the Italian Maritime Rescue Coordination Centre (MRCC), which instructed both the NGO vessel Sea Watch and the LCG's patrol vessel Ras Jadir to direct themselves towards the boat in distress. This latter vessel had been donated by Italy to Libya in May 2017 and eight out of the 13 crew on board had received training by EUNAVFOR MED. Several European vessels and aircraft were nearby, including an Italian navy helicopter. ${ }^{42}$

While it is unclear whether the MRCC designated the Libyan vessel as on scene coordinator and did not inform the NGO vessel or whether the LCG assumed on scene coordination of its own accord, it is alleged that no clear instructions were given and that the NGO ship and LCG could not come to a mutual agreement. It is further alleged that the LCG vessel did not immediately assist the migrants in distress, used a dangerous manoeuvre that endangered the lives of the migrants, and hindered the NGO's rescue operation by throwing objects at the NGO's inflatable boats. The passengers on board the Libyan vessel were cordoned off and beaten. One passenger was hanging on the ladder outside the ship when the LCG left; the LCG slowed down and pulled the person on board after the Italian helicopter repeatedly radioed it to stop. According to testimony, the survivors who were brought back to Libya endured detention in inhumane conditions, beatings, extortion, starvation, rape, slavery and torture. ${ }^{43}$

The incident of 6 November 2017, like the other incidents discussed in the next sections, took place between 20 and 24 nautical miles off the Libyan coast $^{44}$ and are therefore outside Libyan territorial waters. Moreover, as seen in Section 2, the ECtHR held in Hirsi that Italy's obligations under the ECHR are not affected by other legal regimes, including the recent establishment of a Libyan SAR zone.

This case presents many similarities with Hirsi. Both applications focus on a specific incident in which migrants are intercepted in the Mediterranean Sea and returned to Libya. In both cases, the interception takes place in the context

\footnotetext{
41 Global Legal Action Network (n. 4).

42 The analysis only addresses the responsibility of Italy, although it is acknowledged that other EU Member States were indirectly involved in this incident through the presence of vessels or aircraft flying their flag and the fact that eight out of the 13 crew members present on board the LCG vessel had been trained by EUNAVFOR MED.

43 Heller \& Pezzani (n. 3), p. 87-99.

$44 \quad$ Ibid., p. 59, 68 and 88.
} 
of a bilateral agreement between Italy and Libya aimed at preventing migrant arrivals in Italy and which also includes other forms of cooperation. Moreover, both in 2017 and in 2009 returned migrants risk suffering severe human rights violations in Libya and being repatriated to their country of origin.

However, unlike Hirsi, in the GLAN-ASGI case the migrants are intercepted by a Libyan rather than an Italian vessel, and Italy's involvement seems to be limited to partly coordinating the intervention through the M RCC, having donated the LCG's vessel, and the presence of an Italian navy helicopter nearby. Moreover, the EU's involvement is more substantial under current migration control policies than at the time of the Hirsi case. Insofar as the case has been brought only against Italy, the EU's greater involvement may make it more difficult to argue that Italy is responsible. These differences between the two cases are worth exploring in more depth. Before turning to the legal analysis, however, it is worth reflecting on the broader context in which the GLAN-ASGI case is brought to the Court, as it may influence how the Court chooses to address this case. ${ }^{45}$

\subsection{The Broader Context}

The Hirsi case was decided in 2012, almost three years after the pushbacks had taken place and a year after Italy had suspended its cooperation with Libya. It remains to be seen whether the current pullback practices will still be in place when the Court rules on the new case but, if this were the case, the impact of this judgment could be as significant as Hirsi. If the Court invalidates the pullback practices, this would require Italy to revise its migration control policies in the Central Mediterranean. In that sense, the judgment could be compared to MSS $v$ Belgium and Greece ${ }^{46}$ which led to a suspension of transfers to Greece under the Dublin Regulation. However, a decision that does not condemn these practices could be interpreted by Italy and the EU as legitimising the pullback policies. As will be seen below, this could be the case if the application is declared inadmissible because Italy lacked jurisdiction.

\footnotetext{
45 See also Thomas Gammeltoft-Hansen's contribution in this special issue; M. Baumgärtel, 'Part of the Game': Government Strategies against European Litigation Concerning Migrant Rights, in: T. Aalberts \& T. Gammeltoft-Hansen (Eds), The Changing Practices of International Law (Cambridge: Cambridge University Press, 2018), p. 103-128; M. Baumgärtel, High Risk, High Reward: Taking the Question of Italy's Involvement in Libyan 'Pullback' Policies to the European Court of Human Rights, EJIL: talk! 14 May 2018, https://www .ejiltalk.org/high-risk-high-reward-taking-the-question-of-italys-involvement-in-libyan -pullback-policies-to-the-european-court-of-human-rights/ (accessed 25 May 2018). MSS v Belgium and Greece [GC] App no 30696/og (ECtHR, 21 January 2011).
} 
The Court may also be careful in thinking about the scope of its judgment in terms of its impact on pullback policies. Indeed, the current practices can be seen as circumventing the Hirsi judgment, whereby Italy hopes to obtain the same result of reducing migration flows as through pushbacks but without incurring any responsibility. ${ }^{47}$ If the Court addresses only the specific facts of the case, thereby condemning one particular aspect of the pullback policies without making any pronouncements on their legitimacy more generally, it may indirectly push Italy to reinforce other forms of cooperation with Libya.

Furthermore, in Hirsi the Court already acknowledged 'the difficulties related to the phenomenon of migration by sea, involving additional complications for States in controlling the borders in southern Europe. ${ }^{48}$ Yet Hirsi was decided before the refugee crisis of 2015-2016, which led to stronger anti-immigration discourses in Europe and a determination on the part of policy makers to stop, or at least reduce, irregular migration flows at all costs. Moreover, the ECtHR faces a number of other challenges, such as calls from States parties to withdraw from the ECHR and Council of Europe Member States reducing or stopping their financial contributions. ${ }^{49}$ The ECtHR may take into account this difficult political context and adopt a cautious approach when deciding on such a politically challenging case, although it has not shied away from controversial decisions in the past.

Indeed, the ECtHR's recent decision in ND and NT $v$ Spain suggests that it may be willing to take a strong stance on migration control despite widespread European support for such policies. The Third Section of the Court found that pushback practices at the border between Morocco and the Spanish enclaves of Ceuta and Melilla amounted to collective expulsions in breach of Article 4

47 I. Mann, Dialectic of Transnationalism: Unauthorized Migration and Human Rights, 1993-2013, 54(2) Harvard International Law Journal 2013, p. 315-391. See also N. Frei \& C. Hruschka, Zur Umgehung des Refoulement-Verbots beim Kampf gegen 'illegale Migration': Eine rechtliche Bewertung der Massnahmen der EU an der zentralen Mittelmeerroute. Asyl 4/2017, p. 8-14; T. Gammeltoft-Hansen, International Refugee Law and Refugee Policy: The Case of Deterrence Policies, 27(4) Journal of Refugee Studies 2014, p. 574-595.

48 Hirsi, para. 122.

49 See for instance W. Worley, Theresa May 'Will Campaign to Leave the European Convention on Human Rights in 2020 Election', The Independent 29 December 2016, https:/www.independent.co.uk/news/uk/politics/theresa-may-campaign-leave-european -convention-on-human-rights-2020-general-election-brexit-a7499951.html (accessed 1 June 2018); J. Rankin, Human Rights Body faces Cash Crisis after Clash with Russia, The Guardian 16 March 2018, https://www.theguardian.com/law/2018/mar/16/human-rights -body-faces-cash-crisis-after-clash-with-russia (accessed 1 June 2018). 
of Protocol No. $4{ }^{50}$ The case is now pending before the Grand Chamber, and the Grand Chamber's judgment in this case may provide an indication as to how strong a stance the ECtHR is willing to take on migration control practices. However, the facts in ND and NT seem more straightforward than in the GLAN-ASG I case, as the Court had already established in Hirsi that pushbacks were prohibited under the ECHR. ${ }^{51}$

It is also worth comparing the ECtHR's approach to two recent decisions of the Court of Justice of the EU. In $X$ and $X v$ Belgium the Court of Justice ruled that EU law did not apply to humanitarian visas, ${ }^{52}$ while in $N F$ the General Court concluded that it did not have jurisdiction over the EU-Turkey deal. ${ }^{53}$ These rulings can be interpreted as a choice by the Court of Justice not to intervene in migration control policies. ${ }^{54}$ While the Court of Justice seems unwilling to condemn current migration control policies, the ECtHR as a human rights court may be in a better position to do so. In any event, the Court has to consider the broader political context when ruling on the GLAN-ASGI case.

\section{First Scenario: Italian Assets are Present on Scene}

As noted in Section 3.2, an Italian helicopter was present on scene during the incident of 6 November. Yet it has also been reported that during an earlier incident on 27 September 2017 an Italian warship notified the LCG of two migrant boats in distress 20 nautical miles off the Libyan coast. The LCG rescued the migrants and returned them to Libya. The Italian warship did not rescue the migrants but provided life vests to them. ${ }^{55}$ It is not clear if the Italian ship also prevented the migrant boats from continuing their journey. ${ }^{56}$ It also seems

50 ND and NT v Spain Apps nos 8675/15 and 8697/15 (ECtHR, 3 October 2017).

51 See A. Pijnenburg, Is ND and NT v Spain the new Hirsi?, EJIL: Talk! 17 October 2017, https:// www.ejiltalk.org/is-n-d-and-n-t-v-spain-the-new-hirsi/ (accessed 19 January 2018).

52 Case C-638/16 X and Xv Belgium, 7 March 2017, ECLI:EU:C:2017:173.

53 Case T-192/16 NF v European Council, 28 February 2017, ECLI:EU:T:2017:128. In September 2018 the Court of Justice dismissed the appeal against the General Court's order as manifestly inadmissible. Joined Cases C-208/17 P to C-210/17 P NF and Others $v$ European Council, 12 September 2018, ECLI:EU:C:2018:705.

54 See for instance T. Spijkerboer, Bifurcation of Mobility, Bifurcation of Law: Externalization of Migration Policy before the EU Court of Justice, Journal of Refugee Studies (forthcoming), https://ssrn.com/abstract=3053891 (accessed 1 June 2018).

55 Heller \& Pezzani (n. 3), p. 68-69. See also Vice News, Italy is Paying Libya to Intercept Migrants on the Mediterranean, VICE News 25 October 2017, https://news.vice.com/ en_us/article/ned4dg/italy-is-paying-libya-to-intercept-migrants-on-the-mediterranean (accessed 26 January 2018).

$5^{6}$ This is suggested by Biondi: P. Biondi, Italy Strikes Back Again: A Push-back's Firsthand Account, Border Criminologies, 15 December 2017, https://www.law.ox.ac.uk/ 
that several merchant and NGO vessels who were in the area and could have been diverted to rescue the migrants were not informed. ${ }^{57}$ Both incidents thus have in common that Italian assets were present on scene.

\subsection{Authority and Control over Persons}

One key issue which the Court has to address in both situations is whether Italy exercised jurisdiction over the intercepted migrants. ${ }^{58}$ As discussed in Section 1, it found in Hirsi that Italy exercised both de jure and de facto control over the migrants by transferring them to Italian ships. In the incidents discussed here, however, it seems that the Italian ship or helicopter did not make physical contact with the migrants or their boat. This presents the Court with a new challenge, as it has not yet been faced with such a situation.

As regards the incident of 27 September 2017 involving the Italian warship, the Court could refer to various earlier cases involving respondent States' vessels. Thus, in Medvedyev the Grand Chamber held that intercepting a boat on the high seas without embarking the people on board but exercising de facto 'full and exclusive control' over the boat and those on board qualifies as exercising jurisdiction..$^{59}$ It further specified in Al-Skeini that what was decisive for jurisdiction triggered by State agent authority and control was 'the exercise of physical power and control over the person in question' 60 and referred to the test of full and exclusive control over a ship in Hirsi. ${ }^{61}$ Following this reading of its case-law, it is unlikely that the Court would find that the Italian ship exercised sufficient authority and control over the applicants to trigger Italy's jurisdiction.

However, it could also choose to refer to other cases which may enable it to adopt a lower threshold in this case. In particular, in Xhavara, which concerned the fatal ramming of an Albanian migrant ship by an Italian military

research-subject-groups/centre-criminology/centreborder-criminologies/blog/2017/12/ italy-strikes (accessed 26 January 2018).

57 Heller \& Pezzani (n. 3), p. 68-69.

58 On extraterritorial jurisdiction see for instance M. Milanovic, Extraterritorial Application of Human Rights Treaties: Law, Principles, and Policy (Oxford: Oxford University Press, 2011); M. Gondek, The Reach of Human Rights in a Globalising World: Extraterritorial Application of Human Rights Treaties (Antwerp: Intersentia, 2009); T. de Boer, Closing Legal Black Holes: The Role of Extraterritorial Jurisdiction in Refugee Rights Protection, 28(1) Journal of Refugee Studies 2014, p. 118-134; M. Duttwiler, Authority, Control and Jurisdiction in the Extraterritorial Application of the European Convention on Human Rights 30(2) Netherlands Quarterly of Human Rights 2012, p. 137-162.

59 Medvedyev and Others $v$ France [GC] App no 3394/o3 (ECtHR, 29 March 2010), para. 67.

6o Al-Skeini, para. 136 .

61 Hirsi, para. 73 . 
vessel in the context of a bilateral agreement between Italy and Albania, the Court did not explicitly address the question of jurisdiction. Although it eventually found the complaint inadmissible for non-exhaustion of domestic remedies, the decision suggests that both Italy and Albania exercised jurisdiction. ${ }^{62}$ Likewise, in Women on Waves Portugal forbade an NGO vessel from entering its territorial waters and placed a military ship close to the NGO vessel to prevent it from doing so. ${ }^{63}$ In this case also, the ECtHR seemed to assume that Portugal exercised jurisdiction. Thus, one could reason that ramming a boat or preventing it from moving forward through the presence of a military vessel triggers jurisdiction because it amounts to 'full and exclusive control'. Alternatively, Xhavara and Women on Waves could be read as applying a lower threshold for jurisdiction. Arguably, under the same reasoning, throwing life vests from a nearby vessel could qualify as an exercise of authority and control and hence trigger jurisdiction.

Moreover, Den Heijer notes that some ECtHR cases could be interpreted as recognising that States have positive obligations towards individuals outside their territory and over whom they do not exercise control, although the case-law is 'scant and hardly accompanied by a well-elaborated doctrine'. ${ }^{64}$ Following this approach, the Court could find that Italy did not comply with its positive obligations on two grounds. First, because the Italian ship did not rescue the migrants itself and, second, because it contacted only the LCG and not a nearby merchant or NGO vessel to do so, as a result of which the migrants were brought to Libya instead of Italy.

Turning to the facts of the GLAN-ASG I application, in which an Italian army helicopter rather than a vessel was present on scene, what does the foregoing tell us about Italy's exercise of jurisdiction? It seems unlikely that the presence of an Italian helicopter would amount to 'full and exclusive control' as in Medvedyev and Hirsi, and, as this incident concerns a helicopter rather than a ship, the cases of Xhavara and Women on Waves are less relevant. Although this situation may come closer to cases involving persons being killed abroad from an airplane or helicopter, the ECtHR's case-law is arguably too scarce and inconclusive to provide a clear answer. Thus, while in its (in)famous Banković decision the Court held that aerial bombings abroad did not trigger the respondent States' jurisdiction, ${ }^{65}$ in Pad it later found that Iranian men

$62 \quad$ Xhavara and Others $v$ Italy and Albania App no 39473/98 (ECtHR, 11 January 2001), pp. 5-6.

63 Women on Waves $v$ Portugal App No 31276/05 (ECtHR, 3 February 2009).

64 Den Heijer (n. 8), p. 48. See for instance Treska $v$ Albania and Italuy [Admissibility] App no 26937/04 (ECtHR, 29 June 2006); Manoilescu and Dobrescu v Romania and Russia App no 6o861/oo (ECtHR, 3 March 2005).

65 Banković, para. 82. 
who were killed by shooting from a Turkish military helicopter in the border area came within Turkey's jurisdiction. ${ }^{66}$ Yet to what extent the mere presence of a helicopter, without shooting or bombing, triggers Italy's jurisdiction, remains unclear.

However, the Court could also choose to look at the various ways in which Italy exercised influence over the situation and examine whether that amounts to sufficient authority and control over the applicants. It could thereby take into consideration the fact that the Libyan vessel had been donated by Italy, that the MRCC and Italian helicopter gave instructions to the LCG, and that Italy had contributed to training by EUNAVFOR MED. If it applies a lower threshold than 'full and exclusive control', it might find that Italy exercised authority and control over the intercepted migrants-and hence jurisdiction. Moreover, it could take into account Italy's positive obligations and rule that Italy did not comply with its positive obligations because it failed to prevent the applicants from being returned to Libya.

In sum, referring to 'outlier cases' and to Italy's positive obligations could lead the Court to find that Italy is responsible for exposing the migrants to a risk of ill-treatment in Libya. This approach would signify a move from its stricter case-law, which suggests that Italy must exercise full and exclusive control over the migrants, towards adopting a lower threshold to trigger extraterritorial jurisdiction.

\subsection{Public Powers}

Alternatively, the ECtHR could draw on another strand of case-law in order to establish that Italy exercises jurisdiction. Indeed, it held in Al-Skeini that a State exercises extraterritorial jurisdiction when, through the consent, invitation or acquiescence of another State, it exercises 'all or some of the public powers normally to be exercised by that Government'.67 Thus, a State is responsible for human rights violations abroad when its authorities carry out executive or judicial functions on the territory of another State 'in accordance with custom, treaty or other agreement' and 'as long as the acts in question are attributable to it rather than to the territorial State' ${ }^{68}$ However, this line of case-law is not well-developed. ${ }^{69}$ While in Al-Skeini the Court developed and applied this

66 Pad and Others $v$ Turkey [Admissibility] App no 60167/oo (ECtHR, 28 June 2007), para. 54.

67 Al-Skeini, para. 135.

68 Ibid.

69 Cases in which the Court seems to have applied this approach include $X$ and $Y v$ Switzerland Apps nos 7289/75 and 7349/76 (EComHR, 17 July 1977); Drozd and Janousek $v$ France and Spain App no 12747/87 (ECtHR, 26 June 1992); Gentilhomme, Schaff-Benhadji and Zerouki v France Apps nos 48205/99, $48207 / 99$ and 48209/99 (ECtHR, 14 May 2002); 
approach in the context of the British military presence in Iraq after the fall of Saddam Hussein, Gammeltoft-Hansen and Hathaway have suggested that it may also apply to migration control policies. ${ }^{70}$

As regards the incidents of 27 September and 6 November 2017, the Court could thus find that rescuing migrants in distress off the Libyan coast is a public power normally to be exercised by Libya. However, as the interceptions took place outside Libyan territorial waters, it cannot be said to have taken place on Libyan territory. ${ }^{71}$ The Court could further establish that they took place in accordance with an agreement, namely the memorandum of understanding between Italy and Libya, and possibly also with SAR obligations in the law of the sea.

Could it also hold that the act in question, namely the interception, is attributable to Italy rather than to Libya? In order to answer this question the Court could refer to the rules on the attribution of conduct laid down in the International Law Commission's Draft Articles on Responsibility of States for Internationally Wrongful Acts (ARSIWA). Article 6 ARsIWA holds: 'The conduct of an organ placed at the disposal of a State by another State shall be considered an act of the former State under international law if the organ is acting in the exercise of elements of the governmental authority of the State at whose disposal it is placed. ${ }^{72}$ This suggests that the conduct of the LCG could be attributed to Italy rather than to Libya if it is established that the LCG exercises elements of the governmental authority of Italy. Whether this is the case, and whether the conduct of the LCG is attributable to Italy rather than to Libya, depends on the specific facts of the case. Whereas the applicants could argue that Libya is in fact carrying out border controls on behalf of Italy, Italy could for instance point to the fact that the LCG is flying the Libyan rather than the Italian flag.

Alternatively, the Court could consider applying a lower attribution standard than Article 6 ARsIWA. Indeed, in some cases the ECtHR seems to have used a lower standard to attribute conduct to the respondent State, namely that of complicity. ${ }^{73}$ In various extraordinary rendition cases the Court thus

Jaloud v the Netherlands [GC] App no 47708/08 (ECtHR, 20 November 2014), paras. 14-53; and Pisariv Moldova and Russia App no 42139/12 (ECtHR, 21 April 2015), para. 33.

70 Gammeltoft-Hansen \& Hathaway (n. 8), p. 266-269.

71 At the time of this incident Libya had not yet declared its SAR zone.

72 International Law Commission, 2001, Draft Articles on Responsibility of States for Internationally Wrongful Acts, Report of the ILC on the Work of its 53rd Session, UN Doc. A/56/10.

73 M. Jackson, Complicity in International Law (Oxford: Oxford University Press, 2015), p. 194; V. Lanovoy, Complicity and its Limits in the Law of International Responsibility (Oxford: Hart Publishing, 2017), p. 326. 
attributes the conduct of the United States to European States: 'the respondent State must be regarded as responsible under the Convention for acts performed by foreign officials on its territory with the acquiescence or connivance of its authorities. ${ }^{74}$ Moreover, the respondent States are also held responsible for the applicants' transfer abroad, where they were exposed to a 'foreseeable serious risk of further ill-treatment and conditions of detention in breach of Article $3{ }^{75}$ However, in those cases the applicants had been on the territory (and hence within the jurisdiction) of the respondent State. So far the Court has not applied this approach in cases where the applicant is not on the territory of the respondent State, nor in the context of the exercise of public powers. In sum, although an argument could be made under this approach, the requirement that the interception be attributable to Italy rather than to Libya could prove an obstacle to finding that Italy exercised jurisdiction through its exercise of public powers. It arguably remains uncertain whether the Court would apply this approach in this case.

In any event, if the Court were to find that Italy did not exercise jurisdiction, it would declare the application inadmissible. On the other hand, if it rules that the case is admissible because Italy exercised jurisdiction, it would resemble Hirsi insofar as the Court could examine on the merits whether Italy breached its obligations under Article 3 ECHR by exposing the applicants to a risk of ill-treatment in Libya. In addition, it could also examine whether Italy was responsible for ill-treatment that amounted to inhuman and degrading treatment when the passengers were on board the Libyan ship. Last, it could examine, as it did in Hirsi, whether there was a risk of chain refoulement from Libya to the applicants' countries of origin. ${ }^{76}$

In addition to the presence of an Italian helicopter on 6 November 2017, Italy was also involved in the interception in other ways, insofar as the Libyan vessel

74 El-Masri $v$ the former Yugoslav Republic of Macedonia App no 39630/o9 (ECtHR, 13 December 2012), para. 206; see also Al Nashiriv Poland App no 28761/11 (ECtHR, 24 July 2014), para. 452; Husayn (Abu Zubaydah) v Poland App no 7511/13 (ECtHR, 24 July 2014), para. 449; Nasr and Ghali $v$ Italy App no 44883/og (ECtHR, 23 February 2016), para. 241; Al Nashiri v Romania App no 33234/12 (ECtHR, 31 may 2018), para. 594; Abu Zubaydah v Lithuania App no 46454/11 (ECtHR, 31 May 2018), para. 581.

75 Al Nashiri v Poland, para. 518; see also Husayn (Abu Zubaydah) v Poland, para. 513; Abu Zubaydah v Lithuania, para. 643; Al Nashiriv Romania, para. 678.

76 Moreover, the Court could also examine, as it did in Hirsi, whether there has been a breach of the prohibition of collective expulsions under Article 4 of Protocol No. 4 to the ECHR. 
had been donated by Italy and the majority of its crew had been trained by EUNAVFOR MED. More generally, UNHCR reports that just under 14,500 persons were rescued by the LCG in $2017 .{ }^{77}$ It therefore seems reasonable to assume that in a number of cases the LCG intercepted migrants without any direct Italian intervention. In those cases Italy's involvement is limited to the fact that it indirectly supports the LCG.

This support consists of the donation of patrol boats to the $\mathrm{LCG}^{78}$ and an Italian naval mission which is to provide technical and logistical support and advice to the Libyan coast guard, reconnaissance capabilities, and support to set up a centre for coordinating operations. ${ }^{79}$ It is also alleged that the Italian military presence in Tripoli served as a communication and coordination centre which made a crucial contribution to the LCG's command and control capabilities. ${ }^{80}$ Italy further contributes to the training of the LCG by the EU's EUNAVFOR MED Operation Sophia, and provides funding for the maintenance of Libyan boats and the training of Libyan crews. ${ }^{81}$ This raises the question: how could the Court address these indirect forms of Italian involvement?

\subsection{Responsibility Link}

Given the various forms of Italian support, ranging from funding and equipping to training and coordinating, the Libyan pullbacks show some similarities with the Court's case-law concerning human rights violations in Transdniestria, which may enable the Court to draw on this strand of case-law. Indeed, in Ilaşcu the ECtHR held that the Moldovan Republic of Transdniestria was set up with Russia's support and remained 'under the effective authority, or at the very least under the decisive influence, of the Russian Federation, and in any event that it survives by virtue of the military, economic, financial and political support given to it by the Russian Federation. ${ }^{82}$ Accordingly, the Court found that there was 'a continuous and uninterrupted link of responsibility on the part of the Russian Federation for the applicants' fate' and the applicants

77 UN High Commissioner for Refugees, Desperate Journeys (Geneva: UNHCR, February 2017), http://www.refworld.org/docid/58b58b184.html (accessed 17 April 2018), p. 13.

78 A. Lewis \& S. Scherer, Italy tries to Bolster Libyan Coast Guard, despite Humanitarian Concern (Tripoli/Aquarius Rescue ship: Reuters, 15 May 2017, https://uk.reuters.com/article/uk-europe-migrants-libya/italy-tries-to-bolster-libyan-coast-guard-despite-humanitarian-concern-idUKKCN18B2EN (accessed 24 May 2018).

79 Amnesty International (n. 39), p. 46.

$80 \quad$ Heller \& Pezzani (n. 4), p. 49.

81 Amnesty International (n. 39), p. 46.

82 Ilaşcu and Others $v$ Moldova and Russia [GC] App no 48787/99 (ECtHR, 8 July 2004), para. 392 . 
therefore came within the jurisdiction of Russia. ${ }^{83}$ This arguably suggests that support may trigger jurisdiction even if the human rights violation itself is committed by another actor. ${ }^{84}$ The Court has followed this line of reasoning in later Transdniestria cases. ${ }^{85}$

The Court could consider adapting this line of case-law, which concerns a self-proclaimed republic, to the LCG, a State organ. It could thus examine whether Italy's support amounts to effective authority or decisive influence and whether the LCG survives by virtue of the support provided by Italy. Should it find that there is a continuous and uninterrupted link of responsibility and that Italy therefore exercises jurisdiction, it could rule, as it did in Hirsi, that returning migrants to Libya breaches Italy's obligations under Article 3 ECHR. In a similar vein, Moreno-Lax and Giuffré suggest that the funding, training and equipping of Libya by EU Member States can be said to constitute a form of 'decisive influence', which amounts to jurisdiction under Article 1 ECHR. ${ }^{86}$

\subsection{Aid or Assistance}

Yet the Court could also explore another route by drawing on the provisions of the International Law Commission's Draft Articles on Responsibility of States for Internationally Wrongful Acts (ARSIWA), which are commonly accepted as 'an authoritative formulation of international law relating to international responsibility' ${ }^{87}$ In particular, Article 16 ARsiWA holds that:

A State which aids or assists another State in the commission of an internationally wrongful act by the latter is internationally responsible for doing so if:

\footnotetext{
83 Ilaşcu, paras. 393-394.

84 H.P. Aust, Complicity and the Law of State Responsibility (Cambridge: Cambridge University Press, 2011), at p. 412.

85 See Ivanţoc and Others v Moldova and Russia App no 23687/05 (ECtHR, 15 November 2011); Catan and Others $v$ Moldova and Russia [GC] Apps nos 43370/04, 8252/05 and 18454/06 (ECtHR, 19 October 2012); Mozer v Moldova and Russia [GC] App no 11138/10 (ECtHR, 23 February 2016); Turturica and Casian v Moldova and Russia Apps nos 28648/06 and 18832/o7 (ECtHR, 30 August 2016).

86 V. Moreno-Lax \& M. Giuffré, The Rise of Consensual Containment: From "Contactless Control" to "Contactless Responsibility" for Forced Migration Flows, in: S. Juss (Ed.), Research Handbook on International Refugee Law (Cheltenham: Edward Elgar, forthcoming), p. 23-24, http://dx.doi.org/10.2139/ssrn.3009331 (accessed 1 June 2018).

87 A. Nollkaemper, Introduction, in: A. Nollkaemper \& I. Plakokefalos (Eds), Principles of Shared Responsibility in International Law: An Appraisal of the State of the Art, Shared Responsibility in International Law Series (Cambridge: Cambridge University Press, 2014), p. 1-24, at p. 3 .
} 
a) that State does so with knowledge of the circumstances of the internationally wrongful act; and

b) the act would be internationally wrongful if committed by that State.

In other words, if the requirements of Article 16 are met, Italy would incur derived responsibility on account of the aid and assistance it provides to Libya in committing an internationally wrongful act.

If the Court applies Article 16 ARs IWA, it would have to examine whether the requirements of this provision are met, which it has not done before. Although Article 16 ARSIWA has been referred to in extraordinary rendition cases ${ }^{88}$ and in a separate opinion in Hirsi, ${ }^{89}$ the Court has never applied this provision in practice, preferring to incorporate complicity scenarios into the primary human rights norms embodied in the ECHR. ${ }^{90}$ Thus, expulsion amounts to a violation of Article 3 if there is a real risk of exposure to ill-treatment, regardless whether it actually materialises. Therefore, under Article 3 ECHR, unlike under Article 16 ARSIWA, 'the establishment of the expelling state's responsibility is not contingent upon the receiving state committing a wrongful act, but follows directly from the state violating a protective duty in respect of an individual situated in its territory. ${ }^{\prime 91}$ The prohibition of refoulement can thus be seen to function as an alternative to Article 16 ARSIWA.

However, the fact that jurisdiction may be a serious obstacle in the context of the Libyan pullbacks could provide an incentive for the Court to engage more fully with Article 16 ARs IWA in this case. Indeed, whereas Article 3 ECH R only applies when Italy exercises jurisdiction, Article 16 ARSIWA also applies when it does not. Various scholars have also argued that Article 16 applies to Italy's support for the LCG. ${ }^{92}$

Although there seems to be general acceptance that Article 16 ARSIWA is part of customary international law, as recognised by the International Court

88 See El-Masri, para 97; Al Nashiri v Poland, para 207; Husayn (Abu Zubaydah) v Poland, para 201; Nasr and Ghali, para 185; Abu Zubaydah v Lithuania, para. 232; Al Nashiri v Romania, para. 210.

89 Hirsi, Concurring opinion of Judge Pinto de Albuquerque, p. 77.

9o M. den Heijer, Shared Responsibility Before the European Court of Human Rights, 6o(3) Netherlands International Law Review 2013, p. 411-440, at p. 422.

91 Ibid.

92 A. Hirsch \& A. Dastyari, The Ring of Steel: Extraterritorial Migration Controls in Indonesia and Libya and the Complicity of Australia and Italy, Human Rights Law Review (forthcoming). See also Moreno-Lax \& Giuffré (forthcoming) (n. 86). 
of Justice, ${ }^{93}$ its exact contours remain unclear. ${ }^{94}$ There is a lack of jurisprudence and extensive debate among scholars regarding its interpretation. ${ }^{95}$ Accordingly, the ECtHR would have to interpret the requirements of this provision and decide if they are met in this specific case.

Thus, it would first have to determine what constitutes the internationally wrongful act committed by Libya. Article 2 ARSIWA defines an internationally wrongful act of a State as an action or omission which is attributable to the state under international law and constitutes a breach of an international obligation of the State. As regards the events of the GLAN-ASGI case or similar incidents, it could be argued-depending on the exact circumstances of the case - that the ill-treatment of the migrants by the LCG reaches the threshold of Article 7 of the International Covenant on Civil and Political Rights (ICCPR). It could further be argued that returning the migrants to Libya also breaches Article 7 ICCPR as it exposes them to a risk of ill-treatment. ${ }^{96}$ Last, depending on the exact circumstances of the case, it could be argued that the actual ill-treatment of migrants in Libya breaches Article 7 ICCPR, Article 1 of the Convention against Torture (СAT) or the jus cogens prohibition of torture. ${ }^{97}$

Second, the Court would have to assess whether the support provided by Italy to the LCG qualifies as aid or assistance. It is likely that activities such as funding, training, equipping and coordinating qualify as aid or assistance. ${ }^{98}$ However, the fact that some of this support is provided by the EU may make it more difficult to find that Italy's support alone qualifies as aid or assistance,

93 International Court of Justice, Application of the Convention on the Prevention and Punishment of the Crime of Genocide (Bosnia and Herzegovina v. Serbia and Montenegro), ICJ Report (The Hague: ICJ, 2007), p. 43, para. 420.

94 Aust (n. 84), p. 99-100.

95 On the interpretation of Article 16 Arsiwa see for instance J. Crawford, State Responsibility: The General Part (Cambridge: Cambridge University Press, 2013); Aust (n. 84); Jackson (n. 73); Lanovoy (n. 73).

96 It would be more difficult to argue that pullbacks by Libya on the high seas breach the prohibition of refoulement in Article 3 CAT because, although the migrants have left Libyan territory (the interception took place outside Libya's territorial waters), they are not being returned to another State, as required by Article 3 CAT. It could possibly be argued that pullbacks by Libya breach the customary prohibition of refoulement but this would require establishing that non-refoulement is a customary norm of international law, that Libya is not a persistent objector, and that it also applies to pullbacks (as opposed to pushbacks). Looking beyond Article 3 ECHR, the Court could also examine whether there has been a violation of the right to leave (Article 2(2) of Protocol No. 4) and the prohibition of collective expulsions (Article 4 of Protocol No. 4).

97 Libya has ratified the ICCPR and CAT but not the Refugee Convention.

98 See Crawford (n. 96), p. 402; Jackson (n. 74), p. 153-155; Aust (n. 85), p. $209-210$. 
although the fact that Italy shares responsibility with the EU does not preclude Italy's responsibility. ${ }^{99}$

Third, the Court would have to rule on the closeness of the link between the support provided and the human rights violation. Indeed, although Article 16 does not specify that the causal link (nexus) between the aid or assistance provided and the principal wrongful act must reach a certain level of closeness, the Commentary specifies that ' $[t]$ here is no requirement that the aid or assistance should have been essential to the performance of the internationally wrongful act; it is sufficient if it contributed significantly to that act.'100 Commentators disagree regarding what threshold is required, ${ }^{101}$ with Lanovoy arguing that there is no clear standard yet. ${ }^{102}$ Nevertheless, how the Court defines the violation committed by Libya matters. Indeed, it seems likelier that the Court would find that Italy's support contributed to exposing the migrants to a risk of ill-treatment by returning them to Libya than to their actual illtreatment in Libya.

Fourth, Article 16(a) ARSIWA requires that Italy had 'knowledge of the circumstances of the internationally wrongful act'. However, according to the Commentary, 'the aid or assistance must be given with a view to facilitating the commission of the wrongful act, and must actually do so.' ${ }^{103}$ In other words, a key question is whether Article 16 ARsIWA requires knowledge or intent on the part of the aiding or assisting State. What standard is applied, in combination with what counts as an internationally wrongful act, may lead to different outcomes.

Thus, if the standard is knowledge, it may be sufficient for the Court to find that Italy knew about the ill-treatment of migrants at the hands of the LCG, that they would be returned, or that they would be ill-treated. As there have been numerous reports of severe human rights violations suffered by migrants in Libya ${ }^{104}$ as well as indications that the Italian government knew about this, ${ }^{105}$

\footnotetext{
99 See Den Heijer (n. 91).

100 International Law Commission (n. 73), p. 66, para. 5.

101 Compare for example Aust (n. 85), p. 420; Jackson (n. 74), pp. 156-157; Crawford (n. 96), p. 402.

102 Lanovoy (n. 73), p. 184.

103 International Law Commission (n. 73), p. 66, para. 5 .

104 See n. 39.

105 See for instance M. Menduni, Giro: 'Fare rientrare quelle persone vuol dire condannarle all'inferno', La Stampa 6 August 2017, http://www.lastampa.it/2017/08/06/italia/ cronache/giro-fare-rientrare-quelle-persone-vuol-dire-condannarle-allinferno-SXnGzVl zftFl 7 fNGFCMADN/pagina.html (accessed 1 June 2018); V. Passalacqua, The 'Open Arms' Case: Reconciling the Notion of 'Place of Safety' with the Human Rights of Migrants, EJIL: Talk! 21 May 2018, https://www.ejiltalk.org/the-open-arms-case-reconciling-the
} 
this requirement should not be problematic for the Court. As there have also been reports regarding the abusive behaviour of the LCG, the applicants may also be able to prove that Italy knew of the circumstances of the interceptions themselves. ${ }^{106}$

However, if the standard is intent, the applicants would have to show that Italy intended the alleged human rights violations to take place. This would be more difficult as regards the ill-treatment itself, since Italy has also taken measures aimed at improving the situation of migrants in Libya and the EUNAVFOR MED training includes a substantial focus on human rights and international law'. ${ }^{107}$ Some commentators have suggested that the standard may lie between knowledge and intent, approximating knowledge or virtual certainty that the assisted State will use the assistance unlawfully. ${ }^{108}$ Under this threshold, the ECtHR could find that Italy knew or had virtual certainty that Libya would use its support for returning migrants to Libya (and hence exposing them to a risk of ill-treatment).

Last, Article 16(b) also requires that the human rights violation would be internationally wrongful if committed by Italy. Here also, how this requirement is interpreted, in combination with what counts as Libya's internationally wrongful act, may lead to different outcomes. A key question is whether Italy and Libya must be bound by norms that have the same source, or whether it is sufficient for them to be bound by parallel human rights obligations. ${ }^{109}$ If it is sufficient for Italy and Libya to be bound by parallel obligations, the applicants can argue that, although Libya is not a State party to the ECHR, it is bound by an equivalent treaty provision to Article 3 ECHR, namely Article 7 ICCPR. If the same source is required, however, the applicants must show that Libya breached a specific provision of a Convention to which both Libya and Italy are parties, such as Article 7 ICCPR or Article 1 CAT, or a customary norm. In the present case, the applicants could argue that the ill-treatment by the

-notion-of-place-of-safety-with-the-human-rights-of-migrants/\#more-1622o (last accessed 24 May 2018).

106 See for instance Heller \& Pezzani (n. 3), p. 59-61; Amnesty International (n. 39), p. 35-37.

107 European Union External Action, EUNAVFOR MED Operation Sophia Starts Training of Libyan Navy Coast Guard and Libyan Navy, 27 October 2016, https://eeas.europa.eu/ node/13195_en (accessed 1 June 2018).

108 H. Moynihan, Aiding and Assisting: the Mental Element under Article 16 of the International Law Commission's Articles on States Responsibility, 67(2) International and Comparative Law Quarterly 2018, p. 455-471, at p. 468. See also Aust (n. 84), p. 420; Crawford (n. 95), p. 408; Jackson (n. 73), p. 161; Lanovoy (n. 73), p. 240.

109 It can be argued that in the case of human rights violations it would be sufficient for them to be bound by the same norm. Compare Aust (n. 84), p. 263-264; Crawford (n. 95), p. 410; Gammeltoft-Hansen \& Hathaway (n. 8), p. 281. 
Libyan Coast Guard, the return to Libya where they are at risk of ill-treatment, and their ill-treatment in Libya could all qualify as breaches of Article 7 ICCPR, to which both Italy and Libya are bound. This would however raise the question whether the ECtHR's jurisdiction extends to interpreting human rights norms beyond the ECHR.

Indeed, Article 16 ARSIWA confronts the Court with the question of how to apply this provision: the question whether Italy incurs derived responsibility under Article 16 ARsIWA is different from the one the Court has to answer, namely whether Italy breached its obligations under the ECHR. In fact, the challenge is threefold. First, while jurisdiction is not a requirement for establishing responsibility under Article 16 ARSIWA, it is under Article 1 ECHR: if the Court finds that Italy did not exercise jurisdiction, it will declare the case inadmissible and not have the opportunity to address Article 16 ARsiwA. Second, the ECHR on its face does not prohibit Italy from aiding or assisting the commission of human rights violations by Libya. Rather, it places obligations on Italy not to commit human rights violations itself. Yet the Court's jurisdiction is limited to the establishing whether or not Italy complied with its obligations under the ECHR. On the other hand, the ECtHR has repeatedly held that the provisions of treaties must be interpreted in good faith in the light of the object and purpose of the treaty and in accordance with the principle of effectiveness.'110 Last, in order to apply Article 16 ARsiwA, the Court would have to find that Libya committed an internationally wrongful act. However, its jurisdiction is limited to the responsibility of State parties under the ECHR. The Court has indeed confirmed that it should not rule on the lawfulness of activities of non-State parties. ${ }^{111}$ It has thus repeatedly held that 'there is no question of adjudicating on or establishing the responsibility of the destination country, whether under general international law, under the Convention or otherwise.'112 Nevertheless, in expulsion or extradition cases involving nonState parties, the Court indirectly assesses the situation in the receiving country in order to establish the responsibility of the expelling or extraditing State. ${ }^{113}$ The Court could refer to these precedents to (indirectly) establish that Libya committed an internationally wrongful act.

110 Hirsi, para. 179. See also Mamatkulov and Askarov v Turkey [GC] Apps nos 46827/99 and 46951/99 (ECtHR, 4 February 2005) para. 123.

111 M. den Heijer, Procedural Aspects of Shared Responsibility in the European Court of Human Rights, 4(2) Journal of International Dispute Settlement 2013, p. 361-383, at p. 373.

112 Soering v United Kingdom App no 14038/88 (ECtHR, 7 July 1989) para. 91.

113 Den Heijer (n. 111), p. 374. 
One solution to these challenges could be for the Court to read Article 16 ARSIWA into Article $3 \mathrm{ECHR}$, by interpreting the latter as including a prohibition of aiding or assisting another State in breaching the prohibition of illtreatment. Thus, if another State breaches Article 3 and the respondent State is responsible under Article 16 ARsIWA for aiding or assisting the ill-treatment, the Court could hold that the respondent State breached its obligations under Article 3. This interpretation can be seen to build on the Court's existing interpretation of Article $3 \mathrm{ECHR}$ as including a prohibition of refoulement and positive obligations more generally. Following this reasoning, Italy could be found to exercise jurisdiction and breach its obligations under Article 3 ECH R because it aided and assisted the LCG in returning the applicants to Libya. However, this interpretation would go beyond existing case-law. ${ }^{114}$

In sum, whether the Court finds that Italy incurs responsibility under Article 16 would depend on its determination of the facts of the case and on its interpretation of the requirements of Article 16 ARSIWA, as well as its understanding of this provision's relation to Article 3 ECHR. Therefore, although Article 16 could prove a useful tool, it also presents the Court with many challenges which would require it to venture into uncharted territory.

Third Scenario: The Italian Authorities Give Instructions

As noted in Section 3.2, on 6 November 2017 the M RCC instructed both the LCG and the NGO vessel to head towards the boat in distress, while the Italian helicopter asked the Libyan vessel to stop when it was departing. Likewise, various other incidents have been reported whereby the M RCC in Rome gave instructions which led to migrant boats being rescued by the LCG instead of NGO ships. ${ }^{115}$ For instance, on 10 May 2017 the Italian MRCC received a distress call from a migrant boat and requested the NGO ship Sea Watch to intervene, but later instructed it to stand by because the LCG would be taking over on-scene

114 In a similar vein, Jackson suggests that the ECtHR should interpret Article 3 ECHR as prohibiting States parties from facilitating ill-treatment by other actors, both on their territory and abroad. See M. Jackson, Freeing Soering: The EcHR, State Complicity in Torture and Jurisdiction, 27(3) European Journal of International Law 2016, p. 817-830; see also Jackson (n. 73), p. 199; D. Davitti \& M. Fries, Offshore Processing and Complicity in Current EU Migration Policies (Part 2), EJIL: Talk! 11 October 2017, https://www .ejiltalk.org/offshore-processing-and-complicity-in-current-eu-migration-policies-part-2/ (accessed 19 September 2018).

115 Heller \& Pezzani (n. 3), p. 64-82. 
command. The Libyan ship eventually intercepted the migrant boat and returned its passengers to Libya. ${ }^{116}$ These incidents therefore raise the question of Italy's responsibility for giving instructions to the LCG.

\subsection{Extraterritorial Effects}

Arguably, the giving of instructions by the Italian MRCC is a key element in the GLAN-ASGI case and similar incidents. The Court may therefore be called upon to determine whether the giving of instructions by the MRCC triggers Italy's jurisdiction. One path which the Court could explore in this regard is to examine whether the instructions qualify as 'acts that a state controls and carries out on its own territory, leading to a human rights violation on the territory of another state. ${ }^{117}$ Indeed, the Court has repeatedly held that 'acts of the Contracting States performed, or producing effects, outside their territories can constitute an exercise of jurisdiction by them within the meaning of Article 1 of the Convention'.118 A few cases seem to support the view that the extraterritorial effects of State conduct can trigger jurisdiction. They include several incidents in Cyprus whereby the victims were shot by Turkish troops while they were in or next to the buffer zone. ${ }^{119}$ Likewise, in various cases 'the ECtHR

116 Ibid, p. 64-65. See also A. Elumami, Libyan Coastguard turns back nearly 500 Migrants after Altercation with NGo Ship (Tripoli: Reuters, 10 May 2017), https://www.reuters.com/ article/us-europe-migrants-libya/libyan-coastguard-turns-back-nearly-500-migrantsafter-altercation-with-ngo-ship-idUSKBN1862Q2 (last accessed 24 May 2017); J.-P. Gauci, Back to Old Tricks? Italian Responsibility for Returning People to Libya, EJIL: Talk! 6June2017,https://www.ejiltalk.org/back-to-old-tricks-italian-responsibility-for-returning -people-to-libya/ (accessed 11 August 2017).

117 P.V. Kessing, Transnational Operations Carried out from a State's Own Territory: Armed Drones and the Extraterritorial Effect of International Human Rights Conventions, in: T. Gammeltoft-Hansen \& J. Vedsted-Hansen (Eds), Human Rights and the Dark Side of Globalisation: Transnational Law Enforcement and Migration Control, Routledge Studies in Human Rights (Oxford: Routledge, 2017), p. 81-99, at p. 87. See also Gammeltoft-Hansen's contribution in this special issue; K. Da Costa, The Extraterritorial Application of Selected Human Rights Treaties (Leiden: Martinus Nijhoff, 2012), p. 251-252; T. Gammeltoft-Hansen \& J. Vedsted-Hansen, Introduction: Human Rights in an Age of International Cooperation, in: T. Gammeltoft-Hansen \& J. Vedsted-Hansen (Eds), Human Rights and the Dark Side of Globalisation: Transnational Law Enforcement and Migration Control, Routledge Studies in Human Rights (Oxford: Routledge 2017), p. 1-24, at p. 10.

118 Hirsi, para. 72 (emphasis added). See also Banković, para. 67; Al-Skeini, para. 131; Drozd and Janousek, para. 91.

119 Andreouv Turkey [Admissibility] App no 45653/99 (ECtHR, 3June 2008); Solomouv Turkey [Admissibility] App no 36832/97 (ECtHR, 18 may 1999); Isaak v Turkey [Admissibility] App no 44587/98 (ECtHR, 28 September 2006); Panayiv Turkey App no 45388/99 (ECtHR, 27 October 2009). 
accepted that the Convention applied to executive or adjudicative measures which were specifically directed at persons resident abroad'.120

The ECtHR could thus conceive of the MRCC's instructions as an act of the Italian State ${ }^{121}$ taking place on Italian territory (the MRCC is based in Rome) which has extraterritorial effects (the migrant boat was not in Italian territorial waters). However, the ECtHR would have to establish that there is a sufficiently close link between the instructions and the human rights violation. Kessing suggests that the ECtHR requires a direct and immediate causal link between the State act and human rights effect abroad. ${ }^{122}$

The Court would thus have to examine what constitutes the violation of Article 3 in order to assess whether there is a direct and immediate causal link. It could thus hold that the instructions led to the migrants being returned to Libya instead of being brought to Italy. However, Italy would likely argue that it only instructed the LCG to rescue the migrants and not to ill-treat them nor expose them to a risk of ill-treatment in Libya. The Court would therefore probably have to decide whether the fact that Italy knew or should have known that asking the LCG to carry out the rescue would expose the applicants to a risk of ill-treatment is a sufficiently close link. As established by Hirsi, this would be in breach of Article $3 \mathrm{ECHR}$ because the applicants were exposed to the risk of being subjected to ill-treatment in Libya (and possibly chain refoulement).

Moreover, the Court could examine whether the cordoning off, beating, and departing while a person was hanging on the ladder outside the ship reaches the threshold of Article 3. Likewise, there have been other reports of the LCG using threats and violence against migrants and stealing their possessions as well as endangering migrants' lives due to their reckless behaviour. ${ }^{123}$ The Court could therefore examine whether the treatment of the migrants at the hands of the LCG during the interception operation reached the threshold for

120 Den Heijer (n. 8), p. 41. See for instance Haydarie and Others $v$ the Netherlands App no 8876/04 (ECtHR, 20 October 2005); Kovačič and Others v Slovenia Apps nos 44574/98, 45133/98 and 48316/99 (ECtHR, 9 October 2003); Minasyan and Semerjyan v Armenia App no 27651/05 (ECtHR, 23 June 2009).

121 The MRCC in Rome can be considered a State organ in accordance with Article 4 ARSIWA: the annex to the 1979 International Convention on Maritime Search and Rescue requires States parties to make provision for the coordination of the facilities required to provide search and rescue services round their coasts and to establish a national machinery for the overall coordination of search and rescue services by establishing rescue coordination centres.

122 Kessing (n. 117), p. 91 and 93.

123 See for instance Heller \& Pezzani (n. 3), p. 59-61; Amnesty International (n. 39), p. 35-37. 
Article $3 .{ }^{124}$ If this is the case, it could establish Italy's responsibility on the ground that the MRCC's instructions had the extraterritorial effect that the migrants' rights under Article 3 were violated.

\subsection{Direction and Control}

Alternatively, the ECtHR could explore whether Article 17 ARSIWA is applicable in this case. This provision holds that:

A State which directs and controls another State in the commission of an internationally wrongful act by the latter is internationally responsible for that act if:

a) that State does so with knowledge of the circumstances of the internationally wrongful act; and

b) the act would be internationally wrongful if committed by that State.

Article 17 shows many similarities with Article 16 ARSIWA, yet in terms of responsibility its function differs. Whereas under Article 16 Libya remains solely responsible for the pullbacks and Italy is responsible only for the aid or assistance it provides, under Article 17 the responsibility for the pullbacks themselves is attributed both to Libya and to Italy.

However, Articles 16 and 17 ARSIWA present similar challenges as regards their application by the Court. Indeed, although Article 17 ARsIWA, like Article 16, does not require Italy to exercise jurisdiction, without finding that Italy exercises jurisdiction the Court cannot apply this provision. Likewise, on its face the ECHR does not prohibit Italy from directing and controlling another State in committing human rights violations; and the Court does not have jurisdiction to establish Libya's international responsibility.

As for Article 16 ARSIWA, the ECtHR could address these problems by interpreting Article $3 \mathrm{ECHR}$ as including the prohibition of directing and controlling another State in committing human rights violations. Thus, if another State breaches Article 3 and the respondent State is responsible under Article 17 ARsiwA for directing and controlling the ill-treatment, the Court could hold that the respondent State breached its own obligations under Article 3.

If the Court applies Article 17 ARSIWA, it would have to interpret the requirements of this provision and decide if they are met in this case. ${ }^{125}$ First,

124 Under Article $2 \mathrm{ECHR}$ the applicants could also advance the argument that Italy failed to protect the migrants' right to life by instructing the LCG who endangered their lives.

125 See also Moreno-Lax \& Giuffré (n. 86). 
it would have to determine what constitutes the internationally wrongful act committed by Libya. This assessment would be similar to the one discussed with regard to Article 16 ARSIWA in Section 5.2 above. Second, the Court would have to find that the giving of instructions by the MRCC qualifies as direction and control. In that regard, as for Article 16 ARsIWA, it matters which conduct is deemed to constitute an internationally wrongful act on the part of Libya: it would be easier for the Court to find that the MRCC in Rome directed and controlled the migrants' interception and return to Libya than to establish that it directed and controlled the ill-treatment of the intercepted migrants after their return to Libya.

Third, under Article 17 (a) the Court would have to find that Italy knew of the circumstances of the internationally wrongful act. Unlike for Article 16 ARSIWA, the Commentary to Article 17 does not suggest that the applicable standard may be closer to intent than knowledge. As noted above as regards Article 16 ARSIWA, the ECtHR could find that the knowledge requirement is met at least as regards exposing migrants to a risk of ill-treatment by returning them to Libya.

Last, Article 17(b) ARSIWA requires the Court to find that 'the completed act would have been wrongful had it been committed by the directing and controlling State itself.'126 The Commentary to the ARSIWA specifies that

This condition is significant in the context of bilateral obligations, which are not opposable to the directing State. In cases of multilateral obligations and especially of obligations to the international community, it is of much less significance. The essential principle is that a State should not be able to do through another what it could not do itself.'127

Hirsi has already established that returning migrants to Libya breached Italy's obligations under the Convention, and the Court would likely find that if Italian agents ill-treated or tortured migrants this would violate Article 3 ECHR. Thus, it seems that this last requirement would not confront the Court with many difficulties.

More generally, as in the case of Article 16 ARSIWA, whether Italy incurs responsibility under Article 17 depends on the ECtHR's determination of the specific facts of the case and on its interpretation of the requirements of

126 International Law Commission (n. 72), p. 69, para. 8.

127 Ibid. 
Article $17,{ }^{128}$ as well as its understanding of this provision's relation to Article 3 ECHR. Insofar as direction and control suggests a higher level of leverage on the part of Italy, it seems more likely that the requirements of Article 16 ARsIWA are met than those of Article 17 ARsiwA.

This article has discussed different avenues which the ECtHR could explore when deciding on the application filed by GLAN and ASGI, which challenges Italy's involvement in Libyan pullback policies. The foregoing analysis suggests that the Court can draw on different strands of its case-law and refer to various concepts and doctrines when deciding this case. Although none of the approaches discussed above seem to yield a clear answer to the question of Italy's responsibility under the Convention, some avenues may increase the likelihood that the ECtHR will find that Italy exercises jurisdiction and incurs responsibility, while others may limit it. Moreover, although the analysis in this article focused on specific elements of the case, the Court can of course combine various approaches when examining the case as a whole. Thus, while it may find that a specific element may not be sufficient to trigger Italy's jurisdiction and/or responsibility, it may rule that the accumulation of factors does.

It seems that the biggest challenge for the applicants will be to convince the Court that Italy exercised jurisdiction. The Court, in turn, could draw on various strands of case-law, some of which may enable it to find that Italy exercised jurisdiction. It could also refer to the law of State responsibility, especially Articles 16 and 17 ARSIWA, in order to assess whether Italy is responsible. More specifically, it seems that the bolder the Court is in terms of treading uncharted territories, both in terms of establishing that Italy exercised jurisdiction and applying the provisions on derived responsibility in the ARSIWA, the more likely it is to find that Italy is responsible. While the facts of this case may thus prompt the ECtHR to engage with broader international law norms, it may also choose to 'play it safe' both legally and politically by staying within the boundaries of its existing case-law. On the other hand, although the context of this case may not be propitious for such an undertaking, neither would it be the first time that the Court takes it case-law, and thereby human rights protection, a step further.

128 Moreno-Lax \& Giuffré (n. 86) suggest that EU Member States may incur responsibility for Libyan pullbacks under Article 17 ARSIWA. 